\title{
Degradation of Poly(Butylene Succinate) and Poly(Butylene Succinate)/Poly(Lactide) Blends using Serine Protease Produced from Laceyella sacchari LP175
}

\author{
Srisuda Samaimai ${ }^{1}$, Sukhumaporn Krajangsang ${ }^{2}$, Vichien Kitpreechavanich ${ }^{3}$, \\ Jednipit Borthong ${ }^{4}$ and Thanasak Lomthong ${ }^{4, *}$ \\ ${ }^{I}$ Faculty of Science and Technology, Suan Dusit University, Bangkok 10700, Thailand \\ ${ }^{2}$ Department of Microbiology, Faculty of Science, Srinakharinwirot University, Bangkok 10110, Thailand \\ ${ }^{3}$ Department of Microbiology, Faculty of Science, Kasetsart University, Bangkok 10900, Thailand \\ ${ }^{4}$ Division of Biology, Faculty of Science and Technology, Rajamangala University of Technology \\ Thanyaburi, Pathum Thani 12110, Thailand
}

('Corresponding author's e-mail: thanasak_l@rmutt.ac.th)

Received: 4 April 2021, Revised: 26 May 2021, Accepted: 4 June 2021

\begin{abstract}
The thermophilic filamentous bacterium Laceyella sacchari LP175 was cultivated in a $10.0 \mathrm{~L}$ airlift fermenter to produce serine protease at $50{ }^{\circ} \mathrm{C}$. Maximal serine protease activity at $1,123.32 \pm 15.8 \mathrm{U} / \mathrm{mL}$ was obtained for cultivation at $0.6 \mathrm{vvm}$ aeration rate for $36 \mathrm{~h}$. The crude enzyme was applied for degradation of poly (butylene succinate) (PBS), and poly (butylene succinate)/poly(lactide) blend (PBS/PLA) powders at $50{ }^{\circ} \mathrm{C}$ for $48 \mathrm{~h}$ with different substrates and enzyme concentrations. Results showed that serine protease produced from $L$. sacchari LP175 degraded PBS and PBS/PLA at $46.5 \pm 2.05$ and $49.8 \pm 1.45 \%$, respectively, at an initial substrate concentration of $100 \mathrm{~g} / \mathrm{L}$ with $1,200 \mathrm{U} / \mathrm{mL}$ of serine protease activity. Percentage degradation of PBS and PBS/PLA was improved to $51.4 \pm 1.06$ and $56.9 \pm$ $1.42 \%$, respectively, when upscaled in a $2.0 \mathrm{~L}$ stirrer fermenter with $200 \mathrm{rpm}$ agitation rate. Degradation products evaluated by a scanning electron microscope (SEM) and Fourier transform infrared spectroscopy (FTIR) confirmed that serine protease produced from L. sacchari LP175 degraded both PBS and PBS/PLA polymers. Results showed that microbial enzyme technology could be used to degrade PBS and PBS/PLA blend polymers and reduce the accumulation of waste.
\end{abstract}

Keywords: Poly(butylene succinate) (PBS), Polybutylene succinate/poly(lactide) (PBS/PLA) blend, Laceyella sacchari LP175, Serine protease production, Biodegradation

\section{Introduction}

Nowadays, biodegradable aliphatic polyesters have replaced conventional non-degradable materials that caused environmental problems from the limitations of landfill capacity [1]. Poly(butylene succinate) (PBS) and poly(butylene succinate)/poly(lactide) blend polymers (PBS/PLA) with low production costs are used as substitutes for routine plastics. Compared to PLA material, they have reduced brittleness and improved toughness and degradation ability [2-4]. PBS is an aliphatic polyester polymer, produced from the condensation of succinic acid (SA) and 1,4-butanediol (BD) [5,6]. At the same time, PLA is a polymer of lactic acid obtained from the fermentation of various renewable materials, and produced by the condensation polymerization process [7]. PBS and PLA take a long time to completely degrade in natural environments. Shaiju et al. [8] reported that PBS degraded by less than $5.0 \%$ after 10 weeks of seawater immersion. Other processes are required to accelerate the degradation of these polymers to reduce the volume of waste generated from consumer utilization. Recent reports on PBS and PBS/PLA degradation by microbial enzymes such as lipase from Cryptococcus sp. MTCC 5455 [1], cutinase from Fusarium sp. [9] and protease from Amycolatopsis sp. strain SCM_MK2-4 [10] show an increase in the degradation rate of polyester biodegradable plastics.

Laceyella sacchari LP175 showed PLA-degrading enzyme production characterized as serine protease activity $[11,12]$. This utilized low-cost substrates for growth and enzyme production in a $3.0 \mathrm{~L}$ airlift fermenter, yielding $94.4 \mathrm{U} / \mathrm{mL}$ [13]. Crude enzyme obtained from L. sacchari LP175 degraded PLA polymer and poly(lactide)/thermoplastic starch blend film at $50{ }^{\circ} \mathrm{C}$. Optimal conditions for 
degradation of PLA polymer at $100 \mathrm{~g} / \mathrm{L}$ by crude enzyme produced from L. sacchari LP175 were reported at $\mathrm{pH} 9.0$, with $0.2 \mathrm{M}$ of buffer concentration yielding $68 \%$ degradation [14]. However, upscale for enzyme production in a 10.0 airlift fermenter by the LP175 strain and application for PBS and PBS/PLA degradation has not been reported.

Each microorganism has optimal growth conditions. Aeration rate is a highly important factor in an airlift fermenter that does not contain an agitation system compared with a stirrer fermenter [12,13]. Thus, the effect of aeration rate on serine protease production by $L$. sacchari LP175 in a $10.0 \mathrm{~L}$ airlift fermenter was investigated. Optimal conditions for degradation of PBS and PBS/PLA blend powders by crude enzyme were also assessed.

\section{Materials and methods}

\section{Microorganism}

The bacterial strain, L. sacchari LP175 was grown in nutrient broth (NB) at $50{ }^{\circ} \mathrm{C}$ for $24 \mathrm{~h}$ as described by Lomthong et al. [15]. A cell suspension of LP175 strain $\left(1 \times 10^{7} \mathrm{CFU} / \mathrm{mL}\right)$ after the centrifugation at $10,000 \mathrm{rpm}$, at $4{ }^{\circ} \mathrm{C}$ was suspended in sterile $0.85 \% \mathrm{NaCl}$ solution and used as the inoculum.

\section{Enzyme production in a $10.0 \mathrm{~L}$ airlift fermenter}

Serine protease production was carried out in a $10.0 \mathrm{~L}$ airlift fermenter using $7.0 \mathrm{~L}$ working volume of the optimized medium; $4.64 \mathrm{~g} / \mathrm{L}$ cassava chips, $1.53 \mathrm{~g} / \mathrm{L}$ soybean meal and $0.31 \mathrm{~g} / \mathrm{L}$ PLA powder, $\mathrm{pH}$ 7.0 [13]. The fermentation was conducted at $50{ }^{\circ} \mathrm{C}$ with different aeration rates of $0.2-1.0$ vvm for $36 \mathrm{~h}$. Protease activity was determined using $0.6 \%(\mathrm{w} / \mathrm{v})$ casein in $0.1 \mathrm{M}$ Tris- $\mathrm{HCl}, \mathrm{pH} 9.0$ as substrate, modified from the method of Jarerat et al. [16]. The reaction of $0.5 \mathrm{~mL}$ of enzyme sample and $2.5 \mathrm{~mL}$ of substrate was incubated at $50{ }^{\circ} \mathrm{C}$ for $10 \mathrm{~min}$ and terminated by adding $5 \mathrm{~mL}$ of $0.3 \mathrm{M}$ trichloroacetic acid solution. An aliquot of $2.0 \mathrm{~mL}$ of clear solution after 20 min termination was reacted with $5 \mathrm{~mL}$ of $6 \%$ $(\mathrm{w} / \mathrm{v}) \mathrm{Na}_{2} \mathrm{CO}_{3}$ and $1.0 \mathrm{~mL}$ of $1.0 \mathrm{M}$ Folin-Ciocalteu phenol reagent (Sigma). The reaction was incubated at $30{ }^{\circ} \mathrm{C}$ for $30 \mathrm{~min}$ and liberated L-tyrosine was determined at $660 \mathrm{~nm}$ using L-tyrosine as standard. One unit of protease activity was defined as the amount of enzyme required to liberate $1 \mu \mathrm{mol}$ of L-tyrosine per min.

The time course of enzyme production and growth of $L$. sacchari LP175 in a $10.0 \mathrm{~L}$ airlift fermenter using the optimal aeration rate was investigated. Samples were determined every 12 for $36 \mathrm{~h}$. The obtained enzyme was concentrated using a freeze dryer (Oeron FDU-8624, Korea) and dissolved in a 0.2 $\mathrm{M}$ Tris- $\mathrm{HCl}$ buffer, $\mathrm{pH} 9.0$ as an enzyme for degradation of PBS and PBS/PLA in further experiments $[14]$.

\section{Enzymatic degradation of PBS and PBS/PLA blends}

Powder preparation of PBS and PBS/PLA blends

PBS powder was prepared by dissolving $2.0 \mathrm{~g}$ of PBS pellets (FZ91PD, Mitsubishi Chemical Corporation, Japan) in $100 \mathrm{~mL}$ of chloroform (Merck, Germany). The dissolved solution was poured into a stainless steel tray which contained aluminum foil covered on the surface. The reaction was dried overnight at room temperature. The obtained dried powder was used to investigate degradation ability by the serine protease produced from $L$. sacchari LP175.

PBS/PLA blends were prepared by dissolving $1.0 \mathrm{~g}$ of PBS and $1.0 \mathrm{~g}$ of PLA pellets (Terramac TP4000, Unitika. Co., Ltd., Japan) in $100 \mathrm{~mL}$ of chloroform (Merck, Germany), following the modified method of $\mathrm{Hu}$ et al. [2]. The dissolved solution was poured into a stainless steel tray and the obtained powder was also used for testing degradation by serine protease produced from L. sacchari LP175.

\section{Effect of substrate concentrations on degradation of PBS and PBS/PLA blends}

The hydrolysis of PBS and PBS/PLA was conducted in $250 \mathrm{~mL}$ Erlenmeyer flasks containing 50 $\mathrm{mL}$ of crude enzyme serine protease produced from L. sacchari $\mathrm{LP} 175$ at $400 \mathrm{U} / \mathrm{mL}$ in $0.2 \mathrm{M}$ Tris- $\mathrm{HCl}$ buffer, $\mathrm{pH} 9.0$ with PBS and PBS/PLA at $10-100 \mathrm{~g} / \mathrm{L}$. The reaction mixtures were incubated in a shaking incubator at $150 \mathrm{rpm}$ and $50{ }^{\circ} \mathrm{C}$ for $48 \mathrm{~h}$. Dry weight of the obtained powder after filtration through Whatman $^{\circledR}$ No. 1 filter paper and drying at $50{ }^{\circ} \mathrm{C}$ for $12 \mathrm{~h}$ was used to calculate the percentage degradation according to the equation below, following Lomthong et al. [17]. 
Percentage Degradation $=\underline{(\text { Initial film weight }- \text { Retained film weight })} \times 100$

Initial film weight

\section{Effect of enzyme concentrations on degradation of PBS and PBS/PLA blends}

The effect of enzyme concentrations on the degradation of PBS and PBS/PLA blends was investigated at $400-1600 \mathrm{U} / \mathrm{mL}$ of serine protease activity in $0.2 \mathrm{M}$ Tris- $\mathrm{HCl}$ buffer, $\mathrm{pH} 9.0 \mathrm{with} 100 \mathrm{~g} / \mathrm{L}$ of PBS and PBS/PLA powders. Reaction mixtures were incubated at $150 \mathrm{rpm}$ and $50{ }^{\circ} \mathrm{C}$ for $48 \mathrm{~h}$, and then the dry weight of the retained powder was used to calculate percentage degradation as described previously.

\section{Biodegradation of PBS and PBS/PLA in a 2.0 L stirrer fermenter}

To upscale the degradation of PBS and PBS/PLA blend powders by crude serine protease produced from L. sacchari LP175, the degradation of each bioplastic was conducted in a $2.0 \mathrm{~L}$ stirrer fermenter with $1.0 \mathrm{~L}$ working reaction volume. Enzyme solution in $0.2 \mathrm{M}$ Tris- $\mathrm{HCl}$ buffer $\mathrm{pH} 9.0$ was added to the fermenter with $100 \mathrm{~g} / \mathrm{L}$ of each PBS and PBS/PLA blend powders. The reaction was operated at $50^{\circ} \mathrm{C}$ for $48 \mathrm{~h}$ with $200 \mathrm{rpm}$ agitation rate, as reported by Lomthong et al. [14]. Clear supernatant, after filtration through Whatman ${ }^{\circledR}$ No. 1 filter paper, was used to determine the $\mathrm{pH}$ of the reaction. Both native and digested PBS and PBS/PLA blend powder morphologies were qualitatively assessed by scanning electron microscopy, SEM (model SU8020; Hitachi, Tokyo, Japan). At the end of the reaction, the degraded bioplastic was washed with distilled water, dried at $50{ }^{\circ} \mathrm{C}$ for $24 \mathrm{~h}$, and examined under SEM at $10.0 \mathrm{kV}$. Fourier transform infrared spectroscopy (FTIR, Thermo Scientific Nicolet is5, USA) was used to determine the degraded product spectra of PBS and PBS/PLA blends using a scanning range of 4000 to $500 \mathrm{~cm}^{-1}[1]$.

\section{Statistical analysis}

Results were reported as means of 3 determinations $(n=3)$, and the significance of the data was analyzed by one-way analysis of variance (ANOVA) (SPSS 21.0, USA). Values were considered significant at $p<0.05$ using Duncan's multiple range tests.

\section{Results and discussion}

Serine protease production by $L$. sacchari $\mathrm{LP175}$ in a $10.0 \mathrm{~L}$ airlift fermenter

Results of serine protease production by L. sacchari LP175 at different aeration rates are shown in Figure 1. Maximal enzyme production at $1,123.32 \pm 15.8 \mathrm{U} / \mathrm{mL}$ with productivity of $31.2 \mathrm{U} / \mathrm{mL} / \mathrm{h}$ was found at aeration rate of $0.6 \mathrm{vvm}$. Aeration rate was an important factor for cultivation of L. sacchari LP175 in the airlift fermenter as it improved the heat and mass transfer in the reactor. An airlift fermenter does not contain an agitator compared to a stirrer fermenter [13]. Nadeem et al. [18] reported that the increased aeration rate improved oxygen transfer and nutrient mixing in the fermentation system. $L$. sacchari LP175 is a filamentous bacterium that cannot grow under the shear stress of agitation in a stirrer fermenter. This explains why an airlift fermenter was appropriate for cultivation of L. sacchari LP175 [11]. Low aeration rate of $0.1-0.4 \mathrm{vvm}$ gave insufficient mixing of the reaction and adversely impacted heat and mass transfer. Likewise, high aeration rate of $0.8-1.0 \mathrm{vvm}$ stimulated growth and lysis as characteristic of this bacterial species [11]. Nadeem et al. [18] reported that higher aeration rates than the optimal flow decreased the growth of bacterial cells and alkaline protease production as a result of shear stress and heterogeneous mixing effects. 


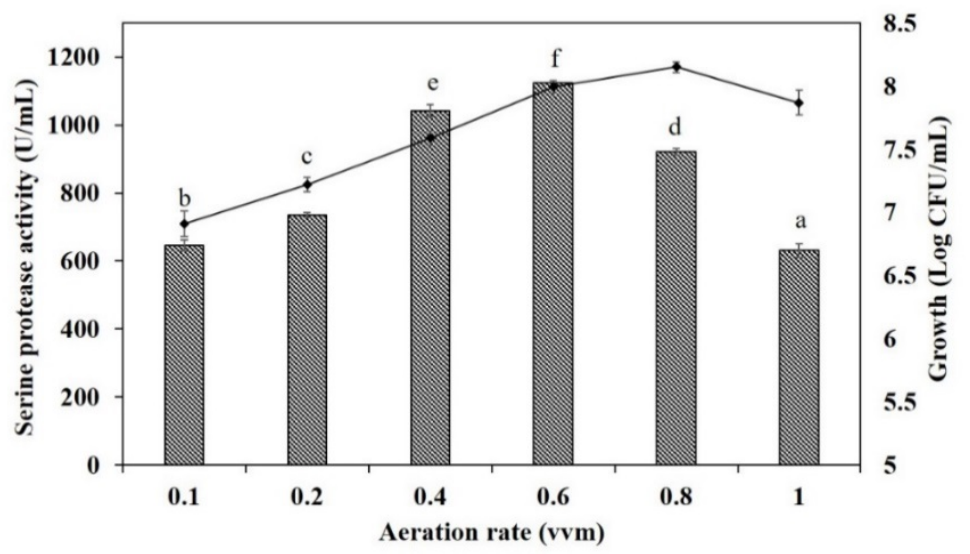

Figure 1 Effects of aeration rate on serine protease production (bar graph) by Laceyella sacchari LP175 in $10.0 \mathrm{~L}$ airlift fermenter at $50{ }^{\circ} \mathrm{C}$ for $36 \mathrm{~h}$. $\bullet$ : Growth of Laceyella sacchari LP175. Error bars $= \pm \mathrm{SD}$, and different lowercase letters above columns indicate significant $(p<0.05)$ difference among means.

Time courses of batch fermentations for serine protease production by L. sacchari LP175 are shown in Figure 2. The serine protease production was started in the early log phase, increasing exponentially during the first $24 \mathrm{~h}$ of fermentation and giving a steady production. This is a progression for serine protease production in a $10.0 \mathrm{~L}$ airlift fermenter using low-cost agricultural products as substrate. Compared with previous reports, enzyme production was obtained at $1330.2 \mathrm{U} / \mathrm{mL}$ with productivity of $27.7 \mathrm{U} / \mathrm{mL} / \mathrm{h}$ by L. sacchari $\mathrm{YNDH}$ using yeast extract as the main substrate, after the incubation at $45^{\circ} \mathrm{C}$

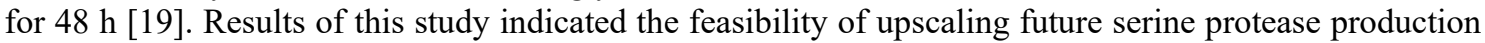
by L. sacchari LP175 at the industrial level using low-cost agricultural products.

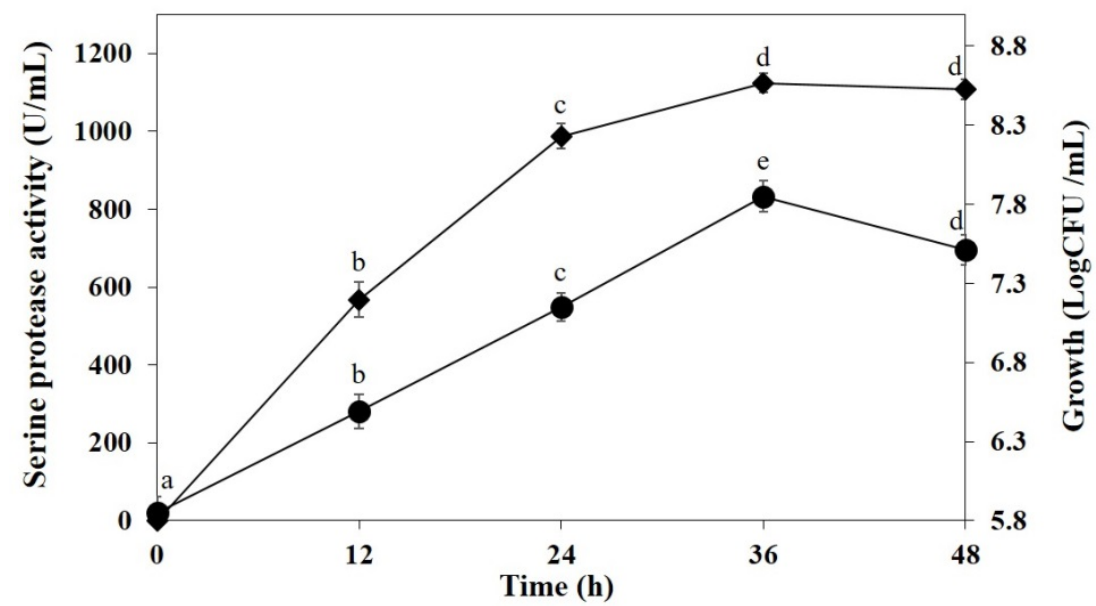

Figure 2 Time courses of batch fermentations for serine protease production by Laceyella sacchari LP175 in a 10.0 L airlift fermenter. $\diamond$ : Serine protease activity, $\mathbf{0}$ : Growth of Laceyella sacchari LP175. Error bars $= \pm \mathrm{SD}$. Different lowercase letters indicate significant $(p<0.05)$ differences among means.

\section{Enzymatic degradation of PBS and PBS/PLA blends}

Effect of substrate concentrations on degradation of PBS and PBS/PLA blends

Bioplastics can be degraded by various microbial enzymes such as esterases, lipases, cutinases and proteases $[10,20]$. Serine protease was reported to degrade polyester polymers such as PBS and PLA by doing the hydrolysis of the ester bonds by Lim et al. [21]. In this study, serine protease produced by $L$. sacchari LP175 was used to investigate the feasibility for the degradation of PBS and PBS/PLA blend powders as described above. Serine protease produced from L. sacchari LP175 degraded both PBS and PBS/PLA blend powders as shown in Table 1. Highest percentage degradation was found using $10 \mathrm{~g} / \mathrm{L}$ of 
PBS and PBS/PLA blend powders at $77.00 \pm 1.41$ and $84.00 \pm 2.83 \%$, respectively. Highest weight loss was found using PBS and PBS/PLA blend powders at $100 \mathrm{~g} / \mathrm{L}$, with reduction of $29.15 \pm 0.21$ and 32.35 $\pm 0.49 \mathrm{~g}$, respectively. Lower percentage degradation at a higher substrate concentration was caused by reduced enzyme activity in the reaction. Further investigations are required to determine the effect of enzyme concentration on percentage degradation of PBS and PBS/PLA at higher substrate concentrations.

Table 1 Effects of substrate concentration on degradation of PBS and PBS/PLA blends by serine protease produced from Laceyella sacchari LP175.

\begin{tabular}{ccccc}
\hline \multirow{2}{*}{$\begin{array}{c}\text { Substrate concentration } \\
\text { (g/L) }\end{array}$} & \multicolumn{2}{c}{ Weight loss (g) } & \multicolumn{2}{c}{ Percentage degradation } \\
\cline { 2 - 5 } & PBS & PBS/PLA & PBS & PBS/PLA \\
\hline 10 & $7.70 \pm 0.14^{\mathrm{a}}$ & $8.40 \pm 0.28^{\mathrm{a}}$ & $77.00 \pm 1.41^{\mathrm{d}}$ & $84.00 \pm 2.83^{\mathrm{d}}$ \\
20 & $13.50 \pm 0.42^{\mathrm{b}}$ & $15.15 \pm 0.21^{\mathrm{b}}$ & $67.50 \pm 2.10^{\mathrm{c}}$ & $75.75 \pm 1.06^{\mathrm{c}}$ \\
50 & $21.60 \pm 0.71^{\mathrm{c}}$ & $26.10 \pm 0.42^{\mathrm{c}}$ & $43.20 \pm 1.41^{\mathrm{b}}$ & $52.20 \pm 0.85^{\mathrm{b}}$ \\
100 & $29.15 \pm 0.21^{\mathrm{d}}$ & $32.35 \pm 0.49^{\mathrm{d}}$ & $29.15 \pm 0.21^{\mathrm{a}}$ & $32.35 \pm 0.49^{\mathrm{a}}$ \\
\hline
\end{tabular}

Different letters within the same column indicate statistical difference at $p<0.05$.

\section{Effect of enzyme concentrations on PBS and PBS/PLA degradation}

Maximal degradation of PBS and PBS/PLA blends was found at enzyme concentration of 1,200 $\mathrm{U} / \mathrm{mL}$, yielding $46.5 \pm 2.05$ and $49.8 \pm 1.45 \%$, respectively when incubated at $50{ }^{\circ} \mathrm{C}$ for $48 \mathrm{~h}$, as shown in Table 2. Lower enzyme concentration gave a lower degradation due to enzyme hydrolysis limitation of the substrate. In a previous study, Lomthong et al. [13] reported that enzyme concentration affected hydrolysis efficiency of PLA polymer. Optimal enzyme concentration improved hydrolysis efficiency compared to lower and higher enzyme concentrations [13]. To correlate with other studies, $2.5 \mathrm{~g} / \mathrm{L}$ of PBS was degraded by lipase produced from Cryptococcus sp. After the incubation at $30{ }^{\circ} \mathrm{C}$ for $96 \mathrm{~h}$ with shaking at $120 \mathrm{rpm}$ [1]. Hu et al. [2] reported that PBS and PBS/PLA blends were degraded by the enzymatic hydrolysis process, with most PLA components degraded by protease enzyme, while the PLA component in the PBS/PLA blends was not degraded completely. This was explained by the different chemical structure and specificity of the enzyme. PBS/PLA is easier to degrade by serine protease compared to PBS polymer.

Table 2 Effects of enzyme concentration on percentage degradation of PBS and PBS/PLA blends by serine protease produced from Laceyella sacchari LP175.

\begin{tabular}{ccc}
\hline Enzyme concentration $(\mathbf{U} / \mathbf{m L})$ & \multicolumn{2}{c}{ Percentage degradation } \\
\cline { 2 - 3 } & PBS & PBS/PLA \\
\hline 400 & $29.80 \pm 1.46^{\mathrm{a}}$ & $32.60 \pm 1.64^{\mathrm{a}}$ \\
800 & $42.10 \pm 1.17^{\mathrm{b}}$ & $46.40 \pm 0.94^{\mathrm{b}}$ \\
1200 & $46.50 \pm 2.05^{\mathrm{c}}$ & $49.80 \pm 1.45^{\mathrm{c}}$ \\
1600 & $46.30 \pm 1.89^{\mathrm{c}}$ & $49.80 \pm 2.36^{\mathrm{c}}$ \\
\hline
\end{tabular}

Different letters within the same column indicate statistical difference at $p<0.05$.

\section{Biodegradation of PBS and PBS/PLA blends in a 2.0 L stirrer fermenter}

The degradation of PBS and PBS/PLA blend powder was performed in the 2.0 stirrer fermenter with $1.0 \mathrm{~L}$ working volume of the total suspension as described above. Optimal $\mathrm{pH}$ and temperature were 9.0 and $50{ }^{\circ} \mathrm{C}$, respectively as reported by Lomthong et al. [13]. Maximal degradations of PBS and PBS/PLA blend powders in a 2.0 stirrer were $51.4 \pm 1.06$ and $56.9 \pm 1.42 \%$, respectively (Figure 3). The degradation in 2.0 stirrer fermenter increased the hydrolysis efficiency of the reaction due to agitation from the impeller as the main component of the stirrer fermenter that improved bioplastic and enzyme mixing in the reaction. Moreover, the shear force of the impeller stimulated the breakdown of bioplastic structures. Panyachanakul et al. [22] also found that agitation in the stirrer fermenter positively impacted the degradation of bioplastics. Lomthong et al. [14] reported that increasing the agitation rate in the stirrer reactor to $200 \mathrm{rpm}$ accelerated the degradation of PLA polymer $(100 \mathrm{~g} / \mathrm{L})$ by up to $68 \%$. 
The scanning electron micrographs showed that residues of PBS and PBS/PLA samples had reduced rigidity, with the appearance of fractures on the surface structure compared to native samples (Figure 4). Serine protease produced from $L$. sacchari LP175 degraded PLA polymers by hydrolysis, causing loss of rigidity and appearance of fractures [14,23]. Proteolytic enzymes hydrolyzed ester bonds of the bioplastic polyesters due to the similarity in chemical structure between the 1-lactic acid unit in PLA and the 1alanine unit in protein [24].

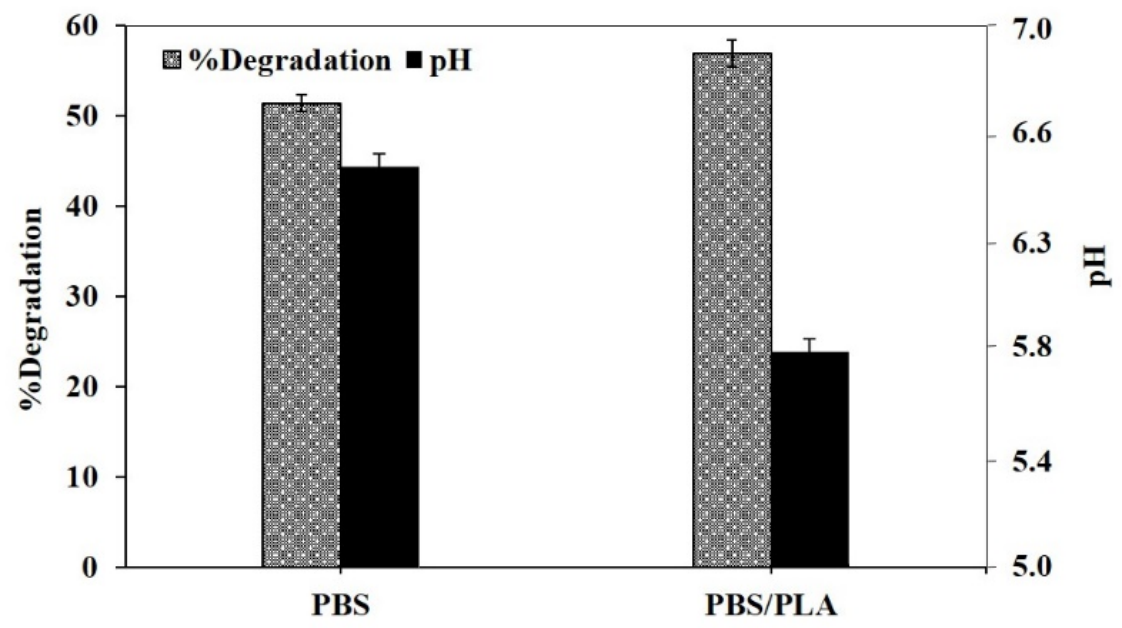

Figure 3 Degradation of poly(butylene succinate) (PBS) and poly(butylene succinate)/poly(lactide) blend polymers (PBS/PLA) by serine protease produced by Laceyella sacchari LP175 in a $2.0 \mathrm{~L}$ stirrer fermenter at $50{ }^{\circ} \mathrm{C}$ for $48 \mathrm{~h}$.

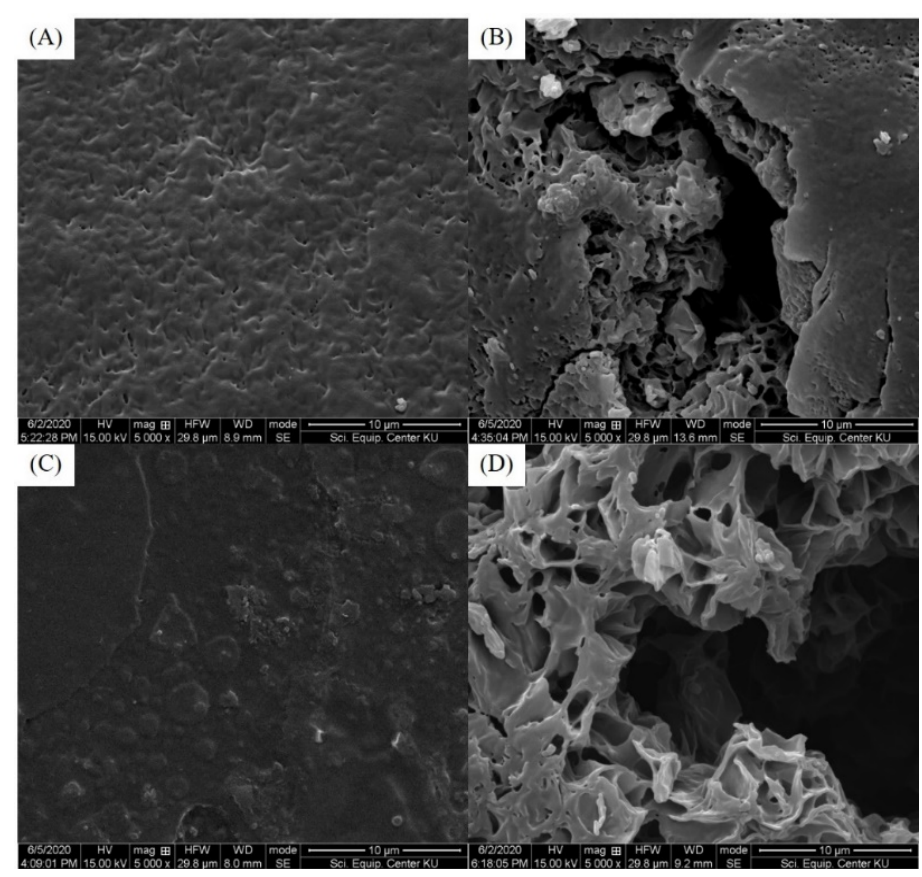

Figure 4 Scanning electron micrographs of native and digested PBS (A, B) and PBS/PLA (C, D) after degradation by serine protease produced from Laceyella sacchari LP175 at $50{ }^{\circ} \mathrm{C}$ for $48 \mathrm{~h}$.

FTIR spectra of the native and degraded products of PBS and PBS/PLA samples are shown in Figure 5. Both native samples of PBS and PBS/PLA blend powders showed similar patterns. The peak at wavenumbers $1708-1714 \mathrm{~cm}^{-1}$ was attributed to the presence of $\mathrm{C}=\mathrm{O}$, while the peak at wavenumbers 
$1150-1164 \mathrm{~cm}^{-1}$ was assigned to the $-\mathrm{C}-\mathrm{O}-\mathrm{C}-$ bond by Thirunavukarasu et al. [1]. The $\mathrm{C}-\mathrm{H}$ bond was found at wavenumber $1327-1335 \mathrm{~cm}^{-1}$. Digested PBS and PBS/PLA samples showed significant changes in transmittance intensity at wavenumbers $1708-1714$ and $1150-1164 \mathrm{~cm}^{-1}$ compared to the native products without enzymatic hydrolysis. Results revealed changes in the chemical structure of PBS and PBS/PLA due to degradation of the $\mathrm{C}=\mathrm{O}$ and $-\mathrm{C}-\mathrm{O}-\mathrm{C}-$ bonds, concurring with Umare et al. [25] and Thirunavukarasu et al. [1].
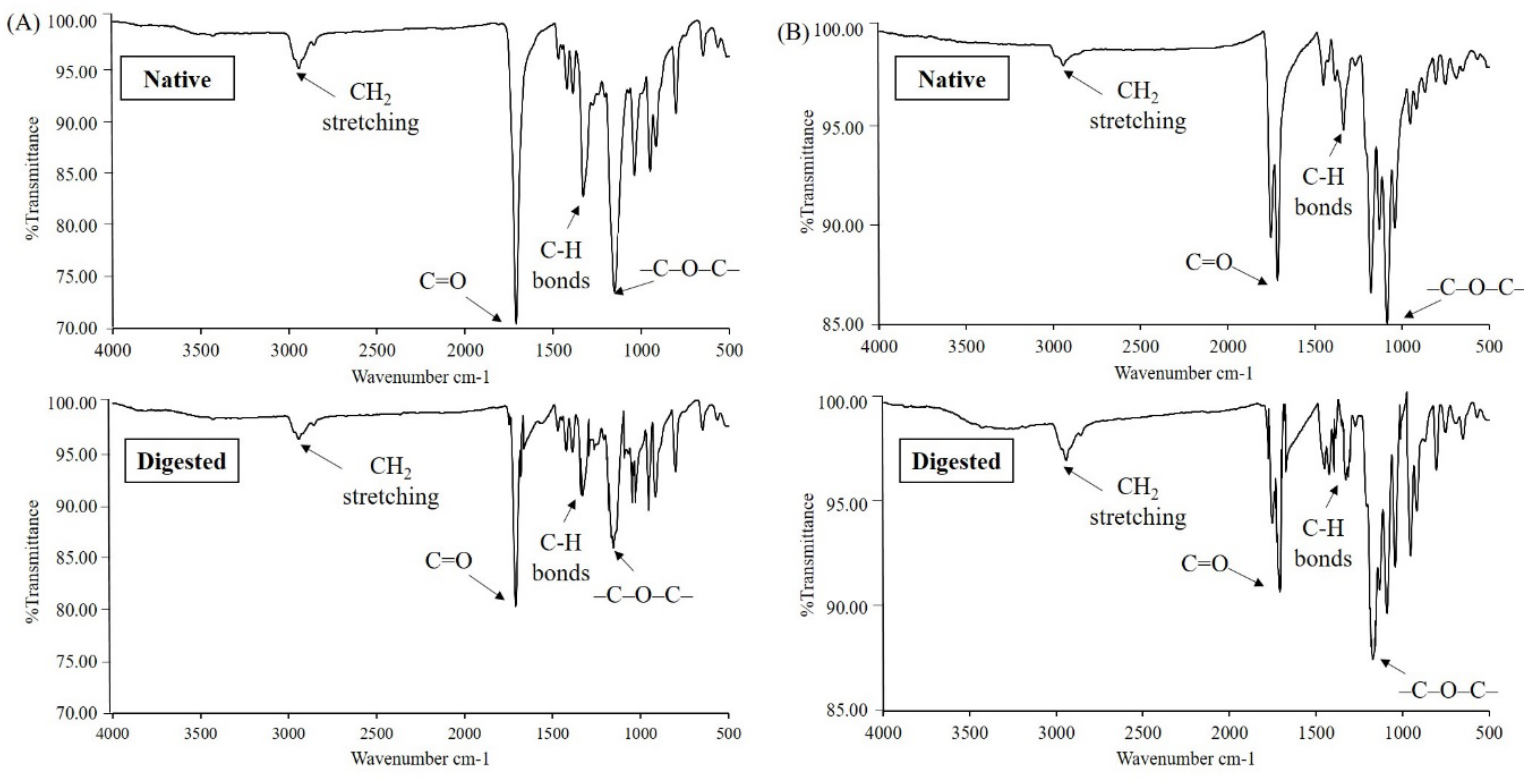

Figure 5 FTIR spectra of native and digested PBS (A), PBS/PLA (B) at wavenumbers 4000 to $500 \mathrm{~cm}^{-1}$.

\section{Conclusions}

The serine protease production was upscaled in a $10.0 \mathrm{~L}$ airlift fermenter using $7.0 \mathrm{~L}$ of working volume. Maximal value was achieved at $0.6 \mathrm{vvm}$, yielding 1,123.32 $\pm 15.8 \mathrm{U} / \mathrm{mL}$ using a low-cost agricultural products of cassava chips and soybean meal as substrates. The crude enzyme degraded both bioplastics PBS and PBS/PLA blend powders under a shaking flask and a 2.0 L stirrer fermenter. Enzyme concentration at $1200 \mathrm{U} / \mathrm{mL}$ accelerated the degradation of PBS and PBS/PLA blends by up to $51.4 \pm$ 1.06 and $56.9 \pm 1.42 \%$, respectively. Results showed a potential application of enzymatic hydrolysis under submerged condition as an alternative method to reduce future accumulation of PBS and PBS/PLA bioplastic wastes.

\section{Acknowledgements}

The authors wish to thank Asst. Prof. Dr. Weraporn Pivsa-Art for kindly providing the PBS and PLA pellets. Thanks are also due to the Faculty of Science and Technology, Rajamangala University of Technology Thanyaburi (RMUTT) for supplying the materials and the use of fermentation machine facilities. 


\section{References}

[1] K Thirunavukarasu, S Purushothaman, J Sridevi, M Aarthy, MK Gowthaman, T Nakajima-Kambe and NR Kamini. Degradation of poly(butylene succinate) and poly(butylene succinate-co-butylene adipate) by a lipase from yeast Cryptococcus sp. grown on agro-industrial residues. Int. Biodeter. Biodegr. 2016; 110, 99-107.

[2] X Hu, T Su, P Li and Z Wang. Blending modification of PBS/PLA and its enzymatic degradation. Polymer Bull. 2018; 75, 533-46.

[3] K Shi, Z Bai, T Su and Z Wang. Selective enzymatic degradation and porous morphology of poly (butylene succinate)/poly (lactic acid) blends. Int. J. Biol. Macromol. 2019; 126, 436-42.

[4] S Su, R Kopitzky, S Tolga and S Kabasci. Polylactide (PLA) and its blends with poly (butylene succinate)(PBS): A brief review. Polymers 2019; 11, 1193.

[5] N Jacquel, F Freyermouth, F Fenouillot, A Rousseau, JP Pascault, P Fuertes and R Saint-Loup. Synthesis and properties of poly(butylene succinate): Efficiency of different transesterification catalysts. J. Polymer Sci. A Polym. Chem. 2011; 49, 5301-12.

[6] M Puchalski, G Szparaga, T Biela, A Gutowska, S Sztajnowski and I Krucińska. Molecular and supramolecular changes in polybutylene succinate (PBS) and polybutylene succinate adipate (PBSA) copolymer during degradation in various environmental conditions. Polymers 2018; 10, 251.

[7] MS Singhvi, SS Zinjarde and DV Gokhale. Polylactic acid: Synthesis and biomedical applications. J. Appl. Microbiol. 2019; 127, 1612-26.

[8] P Shaiju, BB Dorian, R Senthamaraikannan and RB Padamati. Biodegradation of poly(butylene succinate)(PBS)/stearate modified magnesium-aluminium layered double hydroxide composites under marine conditions prepared via melt compounding. Molecules 2020; 25, 5766.

[9] K Shi, T Su and Z Wang. Comparison of poly (butylene succinate) biodegradation by Fusarium solani cutinase and Candida antarctica lipase. Polymer Degrad. Stabil. 2019; 164, 55-60.

[10] W Penkhrue, C Khanongnuch, K Masaki, W Pathom-aree, W Punyodom and S Lumyong. Isolation and screening of biopolymer-degrading microorganisms from Northern Thailand. World J. Microbiol. Biotechnol. 2015; 31, 1431-42.

[11] S Hanphakphoom, N Maneewong, S Sukkhum, S Tokuyama and V Kitpreechavanich. Characterization of poly (L-lactide)-degrading enzyme produced by thermophilic filamentous bacteria Laceyella sacchari LP175. J. Gen. Appl. Microbiol. 2014; 60, 13-22.

[12] T Lomthong, M Guicherd, G Cioci, S Duquesne, A Marty, S Lumyong and V Kitpreechavanich. Poly (L-lactide)-degrading enzyme from Laceyella sacchari LP175: Cloning, sequencing, expression, characterization and its hydrolysis of poly (L-lactide) polymer. Chiang Mai J. Sci. 2019 46, 417-430.

[13] T Lomthong, S Hanphakphoom, P Kongsaeree, N Srisuk, M Guicherd, G Cioci, A Marty and V Kitpreechavanich. Enhancement of poly (L-lactide)-degrading enzyme production by Laceyella sacchari LP175 using agricultural crops as substrates and its degradation of poly (L-lactide) polymer. Polym. Degrad. Stabil. 2017; 143, 64 -73.

[14] T Lomthong, A Areesirisuk, S Suphan, T Panyachanakul, S Krajangsang and V Kitpreechavanich. Solid state fermentation for poly (L-lactide)-degrading enzyme production by Laceyella sacchari LP175 in aerated tray reactor and its hydrolysis of poly (lactide) polymer. Agr. Nat. Resour. 2021; 55, $147-52$.

[15] T Lomthong, S Chotineeranat and V Kitpreechavanich. Production and characterization of raw starch degrading enzyme from a newly isolated thermophilic filamentous bacterium, Laceyella sacchari LP175. Starch/Stärke 2015; 67, 255-66.

[16] A Jarerat, Y Tokiwa and H Tanaka. Production of poly(L-lactide)-degrading enzyme by Amycolatopsis orientalis for biological recycling of poly (L-lactide). Appl. Microbiol. Biotechnol. 2006; 72, 726-31.

[17] T Lomthong, S Hanphakphoom, R Yoksan and V Kitpreechavanich. Co-production of poly(Llactide)-degrading enzyme and raw starch-degrading enzyme by Laceyella sacchari LP175 using agricultural products as substrate, and their efficiency on biodegradation of poly(Llactide)/thermoplastic starch blend film. Int. Biodeterior. Biodegrad. 2015; 104, 401-10.

[18] M Nadeem, JI Qazi and S Baig. Effect of aeration and agitation rates on alkaline protease production by Bacillus licheniformis UV-9 mutant. Turk. J. Biochem. 2009; 34, 89-96. 
[19] DA Goda, AR Bassiouny, NMA Monem, NA Soliman and YRA Fattah. Effective multi-functional biotechnological applications of protease/keratinase enzyme produced by new Egyptian isolate (Laceyella sacchari YNDH). J. Genet. Eng. Biotechnol. 2020; 18, 23.

[20] AK Urbanek, AM Mirończuk, A García-Martín, A Saborido, IDL Mata and M Arroyo. Biochemical properties and biotechnological applications of microbial enzymes involved in the degradation of polyester-type plastics. Biochim. Biophys. Acta Protein Proteonomics 2020; 1868, 140315.

[21] HA Lim, T Raku and Y Tokiwa. Hydrolysis of polyesters by serine proteases. Biotechnol. Lett. 2005; 27, 459-64.

[22] T Panyachanakul, B Sorachart, S Lumyong, W Lorliam, V Kitpreechavanich and S Krajangsang. Development of biodegradation process for poly (DL-lactic acid) degradation by crude enzyme produced by Actinomadura keratinilytica strain T16-1. Electron. J. Biotechnol. 2019; 40, 52-7.

[23] T Lomthong, R Yoksan, S Lumyong and V Kitpreechavanich. Poly(l-lactide)-degrading enzyme production by Laceyella sacchari LP175 under solid state fermentation using low cost agricultural crops and its hydrolysis of poly(l-lactide) film. Waste Biomass Valori. 2020; 11, 1961-70.

[24] A Jarerat and Y Tokiwa. Degradation of poly(l-lactide) by a Fungus. Macromol. Biosci. 2001; 1, 136-40.

[25] SS Umare, AS Chandure and RA Pandey. Synthesis, characterization and biodegradable studies of 1, 3-propanediol based polyesters. Polymer Degrad. Stabil. 2007; 92, 464-79. 